\title{
A Study on the Effects of Perovskia abrotanoides Karel on Experimental Skin Burn in Male Rat: in-vivo and in-vitro Findings
}

\author{
Amin Derakhshanfar ${ }^{1,2} \mathbb{D}$, Seyedeh-Sara Hashemi ${ }^{3 *}{ }^{\mathbb{D}}$ Javad Moayedi $^{1}{ }^{\mathbb{D}}$, Mahjoob Vahedi $^{2}$, \\ Davood Mehrabani ${ }^{4}$ iD, Abuzar Valizadeh ${ }^{2}$ \\ 1. Diagnostic Laboratory Sciences and Technology Research Center, School of Paramedical Sciences, Shiraz University of \\ Medical Sciences, Shiraz, Iran \\ 2. Center of Comparative and Experimental Medicine, Shiraz University of Medical Sciences, Shiraz, Iran \\ 3. Burn and Wound Healing Research Center, Shiraz University of Medical Sciences, Shiraz, Iran \\ 4. Stem Cells Technology Research Center, Shiraz University of Medical Sciences, Shiraz, Iran
}

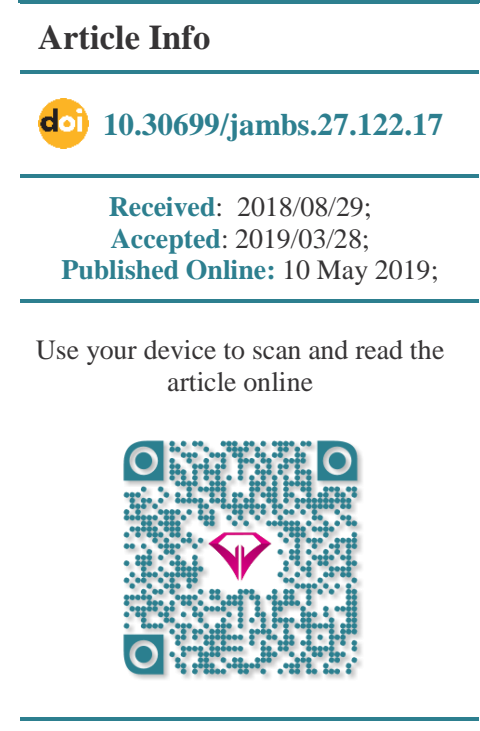

Corresponding Information: Seyedeh-Sara Hashemi, 3.Burn and Wound Healing Research Center, Shiraz University of Medical Sciences, Shiraz, Iran. Email: sara_hashemi@sums.ac.ir

\begin{abstract}
Background \& Objective: Perovskia abrotanoides Karel locally known as Brazambal, is widely used in medical practice to treat various disorders. Burn is a common source of injury and Brazambal ointment has been extensively used in burn wound healing in North of Iran. The purpose of this study was to examine the healing effect of Brazambal ointment in experimental model of burn. In addition, in-vitro healing characteristics and antibacterial activity of $P$. abrotanoides was investigated.

Materials \& Methods: Scald burn injury was produced by pouring $2.5 \mathrm{cc}$ of boiling water $\left(95^{\circ} \mathrm{C}\right)$ on the posterior surface of rat's neck for 10 seconds. Twenty-eight adult male Sprague Dawley rats were divided into 4 groups ( 7 rats each) and followed for 7 days. Control group (no treatment); Silver sulfadiazine-treated group; Brazambal ointment-treated group; and vehicle-treated group received the complete ointment without Brazambal part. The effects of Brazambal aqueous extract on fibroblast cells and antibacterial activity against Escherichia coli, Staphylococcus aureus and Pseudomonas aeruginosa were evaluated.
\end{abstract}

Results: Topical application of Brazambal ointment can accelerate wound healing process by initiating re-epithelialization and formation of granulation tissue. Proliferative activity of the aqueous extract on fibroblast cells was observed after 48 $\mathrm{h}$ in concentrations of $7.5 \%$ and $10 \%(P<0.0001)$. However, $P$. abrotanoides Karel extract had no significant antibacterial effect.

Conclusion: The presence of hair follicles, re-epithelialization and granulation tissue is suggestive of Brazambal ointment relative effectiveness on experimental scald burn in rats. However, further studies are warranted to reveal the healing mechanisms of $P$. abrotanoides.

Keywords: Perovskia abrotanoides, Brazambal, Traditional medicine, Burn

\section{Introduction}

The medicinal plants have been historically proven as a source of therapeutic drugs and are used as primary healthcare in developing countries. They are rich in wide variety of secondary metabolites; in addition, their safety, availability and being economical are the most important advantages of herbals remedies $(1,2)$. The world health organization (WHO) reported that up to $80 \%$ of the world's population relay on traditional medicines for various diseases (3). In Iranian folkloric medicine, $P$. abrotanoides belongs to Lamiaceae family, which is one of the most important medicinal herbs, cultivated in Northern provinces, especially Mazandaran, Golestan, and Khorasan (4,5). It is locally known as Borazambol, Hoosh, Visk, Domou, Gevereh and Brazambal (5-8). The margin of mountainous roads of arid and cold climate of Northern Iran is the main source of $P$. abrotanoides $(5,6)$. Camphor, cineole, caryophyllene, humulene, myrcene, pinene, careen, camphene and bisabolol are the major constituents of the essential oil of Brazambal $(4,9,10)$.

$P$. abrotanoides is used in folkloric medicine to treat wide range of diseases (11). The sedative, analgesic, antioxidant, antimicrobial, anti-plasmodial, antiseptic, anti-inflammatory and cytotoxic effects of Brazambal were evaluated in the previous reports (5,12-15). Iranians have long been using herbal medicine to treat different kinds of diseases, especially skin disorders. In Iranian folkloric medicine, Brazambal was used for the treatment of leishmaniasis $(7,16)$. In addition, its ointment has been extensively used in the healing of wounds and 
burns in the Northern Iran. Therefore, this study was designed to evaluate the potential wound healing effect of $P$. abrotanoides in a reliable in-vivo experimental model of burn according to the histopathological parameters. Moreover, the in-vitro healing characteristics and antibacterial activity were evaluated too.

\section{Materials and Methods}

\section{Ethics}

The study protocol was approved by the local Ethics Committee of Shiraz University of Medical Sciences (SUMS), Shiraz, Iran (Accepted on April 02, 2017, Code: IR.SUMS.REC.1396.S49). Animal care was in accordance with the ethical guidelines.

\section{Collection of the Plant}

The $P$. abrotanoides was collected from Shirvan, North Khorasan Province, Iran. The voucher specimen (PM 937) was collected and deposited at the herbarium of Department of Traditional Pharmacy, School of Pharmacy, SUMS, Shiraz, Iran.

\section{Preparation of herbal extract}

We prepared the aqueous extract of $P$. abrotanoides for in-vitro evaluations. In brief, the dried powders (1000 gr of leaves and flower parts) were transferred into the Soxhlet apparatus filled with distilled water. Afterward, the extract was dried in a water bath and evaporation of its solvent was performed at $45^{\circ} \mathrm{C}$ under vacuum condition.

\section{Folkloric Brazambal ointment}

The ointment formulation consists of the leaves and flowers of the Brazambal, virgin olive oil, black seed, honey wax, ginger, and bee glue. In order to obtain the ointment, Brazambal leaves and flowers (300 g), black seed $(50 \mathrm{~g})$ and ginger $(50 \mathrm{~g})$ were powdered and mixed with virgin olive oil (500 g), and then kept for 10 days. The honey wax $(100 \mathrm{~g})$ and bee glue $(10 \mathrm{~g})$ were heated in a water bath $\left(100^{\circ} \mathrm{C}\right)$, and then added to the herbal mixture. Finally, the mixture was slowly cooled to $5^{\circ} \mathrm{C}$ until congealed.

\section{Extraction and Cultivation of Fibroblast Cells from Human Skin Biopsies}

Human skin samples were obtained aseptically from specimens removed during cosmetic surgeries at hospital affiliated with SUMS. Then, samples were transferred to the cell and tissue engineering laboratory. Primary human skin fibroblast cells were isolated via enzymatic digestion with type-II collagenase (Sigma-Aldrich, USA). Cells were cultured in Dulbecco's modified Eagle's medium(DMEM) supplemented with $20 \%$ fetal bovine serum (FBS) (Gibco Life Technologies, Invitrogen), 1\% L-glutamine (Gibco Life Technologies, Invitrogen), and Pen-Strep (PenicillinStreptomycin) solution at a final concentration of 100 $\mathrm{IU} / \mathrm{mL}$ penicillin and $100 \mu \mathrm{g} / \mathrm{mL}$ streptomycin (Invitrogen). Afterward, the cells were subcultured till the third passage, as described previously $(\mathbf{1 7 , 1 8 )}$.

\section{Cell viability}

To screen the effects of $P$. abrotanoides extract on fibroblast cells in 96-well plates, the extract was dissolved in the respective growth media, described before in various concentrations (w/v) $(5,6,7.5$ and 10 percent) and were incubated for $24,48,72$ hours at $37^{\circ} \mathrm{C}$ and $5 \% \mathrm{CO}_{2}$ while the control group was cultivated with complete DMEM. The media with $P$. abrotanoides extract were then sterilized by filtering through sterile syringe filters $(0.22 \mu \mathrm{m}$ pore size, Fisher Scientific). The cells were seeded at $1 \times 10^{5} /$ well in flat-bottom 96- well culture plates and allowed to grow for 24,48 and $72 \mathrm{~h}$ followed by treatment using different concentration of $P$. abrotanoides extract. After incubation, the medium was removed, and the cells were treated with MTT solution $(5 \mathrm{mg} / \mathrm{mL}$ in PBS) for $4 \mathrm{~h}$. The resultant purple formazan crystals in the viable cells were dissolved by adding $100 \mu \mathrm{L}$ of dimethyl sulfoxide (DMSO) (SigmaAldrich, USA) into each well. After complete solubilization, the optical absorbance of this colored solution was measured at a wavelength of $570 \mathrm{~nm}$ by Elisa Reader, and the cytotoxicity percentage of cells that was affected by different concentration of $P$. abrotanoides extract were calculated by dividing the experimental absorbance of exposed cells (treated wells) to the absorbance of unexposed cells (control well) and then multiplied by 100 . All treatments were carried out in triplicate.

\section{Antibacterial activity}

The antibacterial activity of $P$. abrotanoides extract was assessed against 3 bacterial species: Escherichia coli, Staphylococcus aureus and Pseudomonas aeruginosa, which can cause infection in burn area. Bacterial inoculums were spread over plates containing Mueller Hinton agar, and antibacterial activity was carried out, using the disc diffusion method. The plates were kept in a $37^{\circ} \mathrm{C}$ incubator for 24 hours, and the experiments were performed in duplicate.

\section{Animals and experimental protocol}

Twenty-eight adult male Sprague Dawley rats weighing 200-230 grams were purchased from the Center of Comparative and Experimental Medicine, SUMS, Shiraz, Iran. The subjects were randomly divided into 4 groups (each containing 7 rats): Group 1: Control group received no treatment; Group 2: Silver sulfadiazine-treated group (Sobhan Darou, Iran); Group 3: Brazambal ointmenttreated group; and Group 4: Vehicle-treated group which received the complete ointment without Brazambal part. A maximum of three rats were housed per cage. Prior to the experiment, all the subjects were acclimatized for 2 days under well controlled conditions (12:12 hour light/dark cycle, temperature of $22 \pm 2^{\circ} \mathrm{C}$ ), and given free access to water and a standard pellet diet.

We have developed a reliable and safe model of rat scald burn injury. In brief, under general anesthesia using intramuscular $10 \%$ ketamine $(90 \mathrm{mg} / \mathrm{kg}$ ) and $2 \%$ xylazine (10 $\mathrm{mg} / \mathrm{kg}$ ) (Alfasan, Woerden, Holland), the posterior 
surface of rat's neck was shaved and cleaned with ethanol $70 \%$. Then, the scald burn was made by pouring $2.5 \mathrm{cc}$ of boiling water $\left(95^{\circ} \mathrm{C}\right)$ into the firm rubber ring $(2 \mathrm{~cm}$ diameter). After 10 seconds, the hot water is removed by sterile cotton wool and the animals were placed back in their cages. Each day after the induction of scald burn injury (every 24 hours for 7 days), rats were anesthetized with ketamine and xylazine (40-60 min. of anesthesia) and treatment with topical ointments were carried out. General anesthesia and deep sleep considerably provide better absorption of the ointments. Throughout the experiments, the animals had free access to water and chow.

\section{Assessment of Macroscopic and Mcroscopic Changes}

During the experiment, digital photography (Nikon P610) was used to document the skin changes based on the following aspects: swelling, redness, blistering, bleeding, scar tissue, and infections. At the end of the experiment (day 7), rats were sacrificed with a high dose of ether and the full thickness skin biopsies $(4 \times 4 \mathrm{~cm})$ were taken from the burn site and fixed in $10 \%$ buffered formalin. To prepare the paraffin-embedded tissues, the rat's skin biopsies were placed in the tissue processing machine for 24 hours (DID SABZ co., Iran). After creation of paraffin blocks, serial sections of $5 \mu \mathrm{m}$ thicknesses were cut using a microtome (DID SABZ co., Iran) and stained with hematoxylin-eosin (Merck, Germany). To examine the histopathological skin damage and healing, the slides were assessed under the light microscope by a blinded pathologist who was experienced in burn wound specimens. The inflammatory response, re-epithelialization, and formation of granulation tissue were identified under optical microscope.

\section{Statistical Analysis}

The data were analyzed using SPSS 21 (SPSS Inc., Chicago, IL., USA). The data was analyzed by one-way analysis of variance (ANOVA) and the Bonferroni posthoc test was used for data analysis. A P-value $<0.05$ was statistically significant.

\section{Results}

\section{Cell viability and antimicrobial susceptibility}

Our results showed an increase in proliferative activity of aqueous extract of $P$. abrotanoides on fibroblast cells (Figure 1). The proliferative rate of fibroblast cells after 24 hours in concentration of $7.5 \%$ was lower than that observed in the control group $(P<0.0001)$; however, after 48 hours, the cell growth rate in the concentrations of $7.5 \%$ and $10 \%$ increased significantly $(P<0.0001)$ in comparison to controls. However, the antibacterial activity of aqueous extract was not observed against Escherichia coli, Staphylococcus aureus and Pseudomonas aeruginosa.

\section{Histopathological Findings}

Our method produced a uniform burn with the same depth of tissue damage without any sign of infections, clinical complication or death. Based on the histopathological findings (Table 1), application of Brazambal ointment resulted in an incomplete reepithelialization in all rats in this group (Figure 2d), except for one case, in which epidermis was re-formed completely. In addition to complete epithelialization, newly formed hair follicles were seen in this case at the end of the experiment (day 7) (Figure 2e). In comparison to Brazambal ointment-treated group, no evidence of re-epithelialization was observed in any case of the control (Figure 2a), vehicle-treated (Figure $\underline{2 b})$ and silver sulfadiazine-treated groups (Figure 2c).

Marked inflammation and hemorrhage was not observed in any of the experimental groups and the scab formation was the same in all rats. Compared to other rats in the Brazambal ointment-treated group, scab formation was minimal in the case group which completed the re-epithelialization. In the silver sulfadiazine, vehicle and control group, the extent of granulation tissue was the same while it was observed much more in the Brazambal ointment-treated group.

Table 1. Histopathological scoring system for evaluation of burn wounds

\begin{tabular}{|c|c|c|c|c|}
\hline \multirow{2}{*}{$\begin{array}{l}\text { Histopathological } \\
\text { Findings }\end{array}$} & \multicolumn{4}{|c|}{ Groups } \\
\hline & Control & $\begin{array}{c}\text { Silver } \\
\text { sulfadiazine }\end{array}$ & $\begin{array}{l}\text { Brazambal } \\
\text { ointment }\end{array}$ & Vehicle \\
\hline Re-epithelialization & - & - & $+*$ & - \\
\hline Inflammation & - & - & - & - \\
\hline Hemorrhage & - & - & - & - \\
\hline Fibrinous exudate & - & - & - & - \\
\hline Scab formation & ++ & ++ & $++* *$ & ++ \\
\hline Granulation tissue & + & + & ++ & + \\
\hline
\end{tabular}




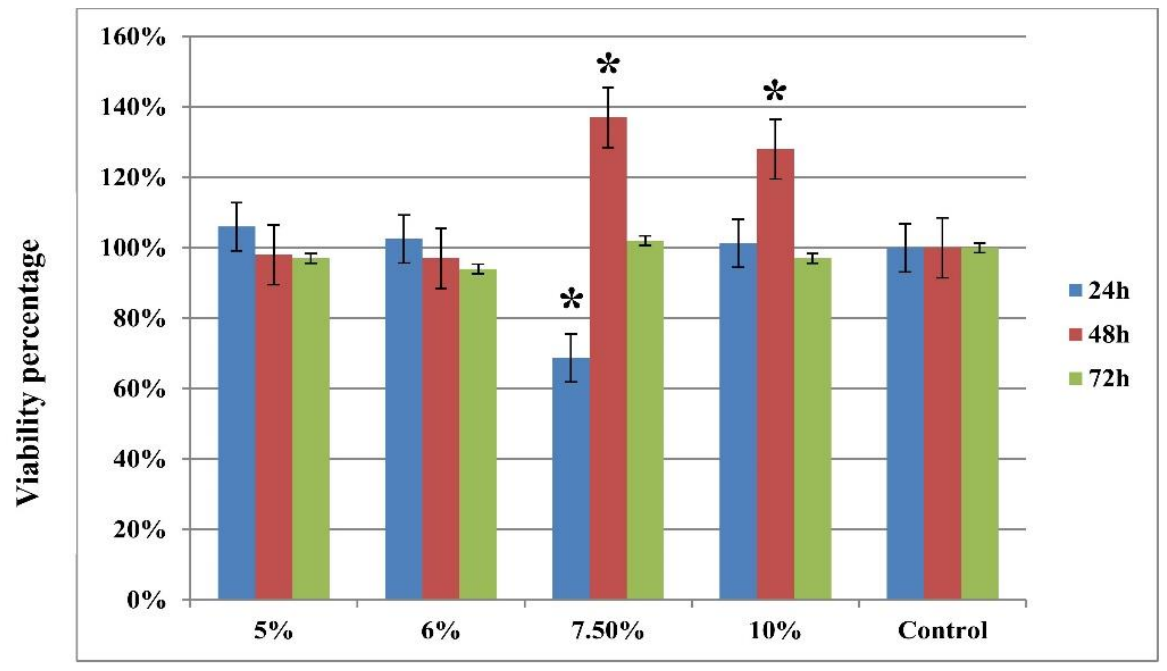

Treatment groups

Figure 1. Proliferative activity in fibroblast cells after 24, 48 and $72 \mathrm{~h}$ of Brazambal-extract treatment. Asterisk $(*)$ shows significant difference with the control group $(P<0.0001)$.

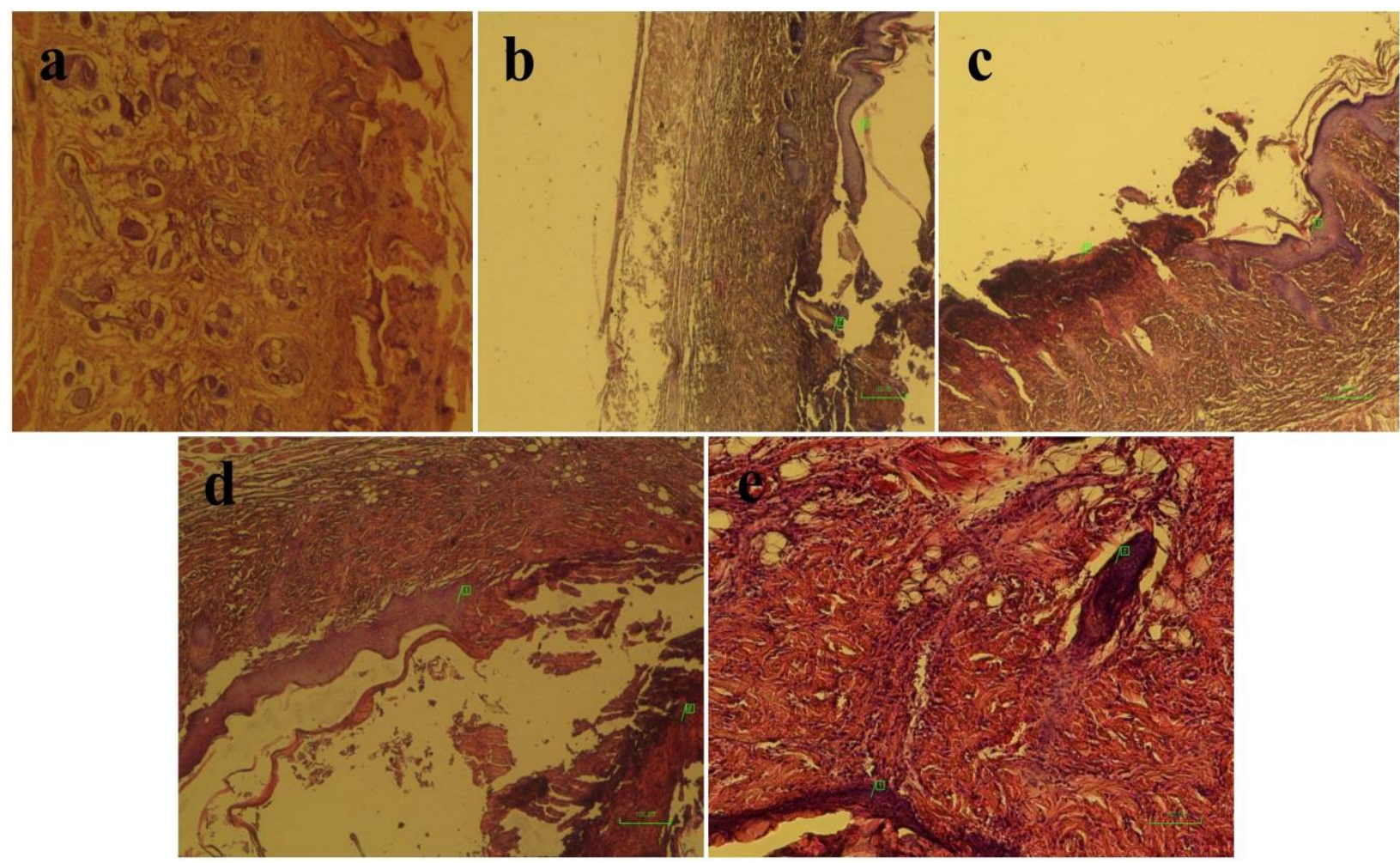

Figure 2. Photomicrograph of the rat's skin during the healing processes. (a) The full-thickness epidermal necrosis with no sign of re-epithelialization $(\times 40, \mathrm{H} \& \mathrm{E})$ in the rat which received no treatment (control group). (b) Vehicle-treated group. The original epidermis (1) is seen at the edge of the ulcer. Re-epithelialization is not occurred and heavy scab (2) is observed above the necrotic epidermis $(\times 40, \mathrm{H} \& \mathrm{E})$. (c) The old/normal epidermis (1) is seen in the rat which received silver sulfadiazine. No sign of reepithelialization with full-thickness necrosis of epidermis (2) and massive scab formation was observed in this group ( $\times 40, \mathrm{H} \& \mathrm{E})$. (d) Incomplete re-epithelialization in the Brazambal ointment-treated group. Note to the newly formed acanthetic epidermis (1). The heavy scab (2) is observed ( $\times 40, \mathrm{H} \& \mathrm{E})$. (e) Complete re-epithelialization (1) and formation of new hair follicle (2) in one case of the Brazambal ointment-treated group. The scab is minimal, and no sign of inflammation and hemorrhage was seen $(\times 100$, $\mathrm{H} \& \mathrm{E})$.

\section{Discussion}

Burn injuries represent the most severe form of trauma with potential local and systemic effects as well as devastating morbidity and mortality (19-21). Managing different kinds of burns is a real clinical 
challenge in the world. As in-vitro models have limited ability to capture all aspects of burn pathophysiology, in-vivo models are more suitable for burn research. Regarding metabolic characteristics and limitations, the general physiology of laboratory animals is similar to that of humans; therefore, they could help researchers to uncover the pathological mechanisms of burn injuries and test the novel therapeutic approaches (19-22). Rodents, especially rat, are the most commonly used animals in burn research that can provide an excellent model for skin wound healing by allowing the standardization of burn characteristics including type, size, shape, and depth of the injuries $(20,21,23,24)$. The current study was carried out to evaluate the burn healing activity of $P$. abrotanoides in an experimental model of scald burn injury. Even though no experimental study has been conducted on the effect of Brazambal in burn injuries, it is widely used in Iranian folkloric medicine to heal burn wounds.

The results of in-vitro assays showed that $P$. abrotanoides extract had a significant proliferative effect on fibroblast cells. Therefore, it could be used as a growth factor in cell culture media. In contrast to our results, Geryani et al. (25) showed cytotoxic and apoptogenic effects of $P$. abrotanoides extract on MCF7 and HeLa cell lines in a time and dose-dependent manner. In the current study, no antibacterial activity of $P$. abrotanoides extract was observed neither against Gram positive ( $S$. aureus) nor Gram negative bacteria (E. coli, and P. aeruginosa). However, Nezhadali et al. (26) reported the bactericidal effects of the essential oil of $P$. abrotanoides against two strains of Gram-negative bacteria (E. coli, Klebsiella pneumonia). In addition, bacteriostatic activity was noted against Gram positive bacteria (Bacillus cereus, S. aureus) (26). The presence of hair follicles, re-epithelialization and granulation tissue suggests the relative effectiveness of Brazambal ointment on experimental scald burn in rats.

\section{Conclusion}

This study showed that Brazambal can accelerate the proliferation of fibroblast cells and increase the rate of granulation tissue formation; therefore, it has a potential effect to accelerate burn wound healing. However, further studies are essential to reveal the healing mechanisms of $P$. abrotanoides.

\section{Acknowledgements}

This study was financially supported by grant No. 9501-45-13677 from Vice-Chancellery of Research at Shiraz University of Medical Sciences, Shiraz, Iran. We would like to express especial thanks to $\mathrm{Mr}$.
Mohammadi and Mr. Ghelichpoor for preparation and providing the folkloric Brazambal ointment. The authors wish to thank Mr. H. Argasi at the Research Consultation Center (RCC) of Shiraz University of Medical Sciences for his invaluable assistance in editing this manuscript.

\section{Conflict of Interest}

The authors had no conflict of interest to declare.

\section{References}

1. Hosseinzadeh S, Jafarikukhdan A, Hosseini A, Armand R. The application of medicinal plants in traditional and modern medicine: a review of Thymus vulgaris. Int J Clin Med. 2015; 6(9): 635-42. [DOI:10.4236/ijcm.2015.69084]

2. Atanasov AG, Waltenberger B, Pferschy-Wenzig E-M, Linder T, Wawrosch C, Uhrin P,et al. Discovery and resupply of pharmacologically active plant-derived natural products: A review. Biotechnol Adv. 2015; 33(8): 1582-614. [DOI:10.1016/j.biotechadv.2015.08.001] [PMID] [PMCID]

3. Ghasemi Pirbalouti A, Koohpayeh A, Karimi I. The wound healing activity of flower extracts of Punica granatum and Achillea kellalensis in Wistar rats. Acta Pol Pharm. 2010; 67(1): 107-10.

4. Shahraki S, Mahdavi S, Hosseini S, Mazandarani M, Tavan M. Investigation quantity and quality of essential oils the Proveskia abrotanoides karel (case study: International park of golestan and kyasar mazandaran). ECO-Phytochem J Med Plant. 2013; 1(3): 68-81.

5. Beikmohammadi $M$. The evaluation of medicinal properties of Perovskia abrotanoides Karel. Middle-East J Sci Res. 2012; 11(2): 189-93.

6. Kolbady Nejad S, Jaimand K, Monfared A, Akbarzadeh M. Study of the chemical composition of essential oils of Perovskia abrotanoides karel at the different stage and distillation by gas chromatography. JMPB. 2013;2(2): 139-42.

7. Mahboubi M, Kazempour N. The antimicrobial activity of essential oil from Perovskia abrotanoides karel and its main components. Indian J Pharm Sci. 2009; 71(3): 343-7. [DOI:10.4103/0250-474X.56016] [PMID] [PMCID]

8. Mazandarani M, Ghaemi E. Ethnopharmacological investigation of different parts of Perovskia abrotanoides Karel. Planta Med. 2010; 76(12): 123. [DOI:10.1055/s-00301264421]

9. Morteza-Semnani K. The essential oil composition of Perovskia abrotanoides from Iran. Pharm Biol. 2004; 42(3): 214-6. [DOI:10.1080/13880200490514078]

10. Sajjadi S, Mehregan I, Khatamsaz M, Asgari G. Chemical composition of the essential oil of Perovskia abrotanoides Karel growing wild in Iran. Flavour Fragr J. 2005; 20(4): 4456. [DOI:10.1002/ff].1508]

11. Moallem SA, Niapour M. Study of embryotoxicity of Perovskia abrotanoides, an adulterant in folk-medicine, during organogenesis in mice. J Ethnopharmacol. 2008; 117(1): 10814. [DOI:10.1016/j.jep.2008.01.020] [PMID]

12. Ashraf SN, Zubair M, Rizwan K, Tareen RB, Rasool N, ZiaUl-Haq M, et al. Compositional studies and biological 
activities of Perovskia abrotanoides Karel oils. Biol Res. 2014; 47(1): $12-20$.

13. Hosseinzadeh $\mathrm{H}$, Amel S. Antinociceptive effects of the aerial parts of Perovskia abrotanoides extracts in mice. Iran Red Crescent Med J. 2001; 4(1): 15-7.

14. Nasiriasl M, Parvardeh S, Niapour M, Hosseinzadeh H. Antinociceptive and anti-inflammatory effects of Perovskia abrotanoides aerial part extracts in mice and rats. J Med Plants. 2002; 1(3): 1-8.

15. Sairafianpour M, Christensen J, Stærk D, Budnik B, Kharazmi A, Bagherzadeh K, et al. Leishmanicidal, antiplasmodial, and cytotoxic activity of novel diterpenoid 1, 2-quinones from Perovskia abrotanoides: new source of tanshinones. J Nat Prod. 2001; 64(11): 1398-403. [DOI:10.1021/np010032f] [PMID]

16. Jaafari MR, Hooshmand S, Samiei A, Hossainzadeh H. Evaluation of-leishmanicidal effect of Perovskia abrotanoides Karel root extract by in vitro leishmanicidal assay using promastigotes of Leishmania major. Pharmacol Online. 2007; 1(1): 299-303.

17. Hashemi S-S, Mahmoodi M, Rafati AR, Manafi F, Mehrabani D. The role of human adult peripheral and umbilical cord blood platelet-rich plasma on proliferation and migration of human skin fibroblasts. World J Plast Surg. 2017; 6(2): 198205

18. Hashemi S, Rafati A. Comparison between human cord blood serum and platelet-rich plasma supplementation for human wharton's jelly stem cells and dermal fibroblasts culture.IJMRHS. 2016; 5(8): 191-6

19. Pereira T, Dos Santos D, Lima-Ribeiro MHM, de Pontes-Filho NT, Carneiro-Leão AMdA, Correia MTdS. Development of animal model for studying deep second-degree thermal burns. J Biomed Biotechnol. 2012; 2012(1): 1-7. [DOI:10.1155/2012/460841] [PMID] [PMCID]

20. Abdullahi A, Amini-Nik S, Jeschke M. Animal models in burn research. Cell Mol Life Sci. 2014; 71(17): 3241-55. [DOI:10.1007/s00018-014-1612-5] [PMID] [PMCID]

21. Qu M, Nourbakhsh M. Current experimental models of burns. Discov Med. 2017; 23(125): 95-103.

22. Campelo APBS, Campelo MWS, Britto GAdC, Ayala AP, Guimarães SB, Vasconcelos PRLd. An optimized animal model for partial and total skin thickness burns studies. Acta Cir Bras. 2011; 26(1): 38-42. [DOI:10.1590/S0102$86502011000700008]$ [PMID]

23. Abdeldjelil M, Messai A, Boudebza A, Beghoul S. Practical aspects to generate cutaneous experimental burns in a rat model. Pharm Lett. 2017; 9(1): 70-84.

24. Guo H-F, Ali RM, Hamid RA, Zaini AA, Khaza'ai H. A new model for studying deep partial-thickness burns in rats. Int $\mathrm{J}$ Burns Trauma. 2017; 7(6): 107-14.

25. Geryani MA, Mahdian D, Mousavi SH, Hosseini A. Ctotoxic and apoptogenic effects of Perovskia abrotanoides flower extract on MCF-7 and HeLa cell lines. Avic J Phy. 2016; 6(4): 410-7.

26. Nezhadali A, Masrornia M, Solati A, Akbarpour M, Nakai Moghaddam M. Analysis of the flower essential oil at different stages of plant growth and in vitro antibacterial activity of Perovskia abrotanoides Karal in Iran. Der Pharma Chemica. 2009; 1(1): 146-50.

\section{How to Cite This Article:}

Derakhshanfar A, Hashemi S, Moayedi J, Vahedi M, Mehrabani D, Valizadeh A. A study on the effects of Perovskia abrotanoides karel on experimental skin burn in male rat: in-vivo and in-vitro findings. J Adv Med Biomed Res. 2019; 27 (122) :17-22

Download citation:

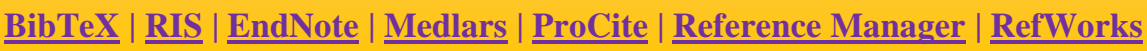

\section{Send citation to:}

Mendeley 2 Zotero RefWorks $\underline{\text { RefWorks }}$ 